\title{
TIME OF MONITORING INFLUENCES DETECTABILITY AND DEMOGRAPHIC ESTIMATES OF THE THREATENED PERENNIAL SPALDING'S CATCHFLY (SILENE SPALDINGII S.WATSON)
}

\author{
Janice L. Hill1,3 and Edward O. Garton ${ }^{2}$
}

\begin{abstract}
The Threatened plant Spalding's catchfly (Silene spaldingii S.Watson) is known to exhibit prolonged dormancy in which individuals survive belowground for one or more years; detection of all aboveground plants is essential for accurate estimates of prolonged dormancy. We conducted 2 long-term demographic studies of Spalding's catchfly in west central Idaho (2002-2013), following 947 plants in permanent plots for 10 consecutive years. To detect all plants emerging aboveground, we monitored twice each growing season-soon after emergence and at flowering-and searched closely for small, inconspicuous stages. Demographic estimates were based on stage-based transition matrix and mark-recapture analyses. Over $99 \%$ of aboveground plants were present and detectable at early monitoring; approximately one-third were rosette plants, most of which represented established plants present in previous years. Annual dormancy was approximately $10 \%$. Detectability declined considerably by flowering (time dependent) and affected the small, ephemeral rosette stage disproportionately (stage dependent). At flowering, $48 \%$ of the plants present aboveground early in the season disappeared or became undetectable or unidentifiable. If we had monitored only at flowering time, we would have considerably underestimated population size, overestimated dormancy, and missed most recruitments. Early monitoring was critical for detecting all aboveground plants, obtaining unbiased demographic estimates, identifying a major vegetative stage class, demonstrating retrogression from larger stemmed to smaller rosette plants, and identifying rodents as a major threat. Our results have implications for other plants with inconspicuous, ephemeral, or dormant stage classes and those with long growing seasons in harsh environments where detectability of aboveground plant tissue may decrease over the growing season.
\end{abstract}

Resumen.-La planta Silene spaldingii S.Watson, en peligro de extinción, es conocida por exhibir una dormancia prolongada en la que los individuos sobreviven bajo tierra durante uno o más años. La detección de todas las plantas en la superficie de la tierra es esencial para estimar con precisión la dormancia prolongada. Realizamos dos estudios demográficos a largo plazo de la planta S. spaldingii en el centro-oeste de Idaho (2002-2013) siguiendo 947 plantas en parcelas permanentes durante 10 años consecutivos. Para detectar todas las plantas que emergen sobre el suelo, monitoreamos dos veces durante la temporada de crecimiento, una inmediatamente después de la germinación y otra después de la floración, y buscamos cuidadosamente las fases pequeñas e imperceptibles. Las estimaciones demográficas se basaron en una matriz de transición basada en estadios y en análisis de marca y recaptura. Más del 99\% de las plantas de la superficie estuvieron presentes y se detectaron tempranamente mediante un monitoreo; aproximadamente un tercio fueron plantas de roseta, la mayoría de las cuales representaban plantas presentes en años anteriores, y la dormancia anual fue del 10\%. La detectabilidad disminuyó considerablemente durante la época de floración (dependiente del tiempo) y afectó de manera desproporcionada la fase pequeña y efímera de la roseta (dependiente de la etapa). Durante la floración $48 \%$ de las plantas presentes sobre el suelo a principios de la estación desapareció o se volvió indetectable o no identificable. Si hubiésemos monitoreado únicamente durante la etapa de floración, hubiésemos subestimado considerablemente el tamaño de la población, sobreestimado la dormancia y perdido la mayoría del reclutamiento. El monitoreo temprano fue fundamental para detectar todas las plantas de la superficie y obtener estimaciones demográficas imparciales, identificando una clase importante de la etapa vegetativa, demostrando el retroceso de tallos grandes a plantas pequeñas de roseta e identificando a los roedores como una amenaza importante. Nuestros resultados tienen implicaciones para otras plantas con etapas poco conspicuas, efímeras o con dormancia y aquellas con largas temporadas de crecimiento en ambientes hostiles donde la detectabilidad del tejido vegetal sobre el suelo puede disminuir durante la temporada de crecimiento.

Accurate demographic estimates rely on detection of a plant that is present (Kéry and Gregg 2003, Kéry et al. 2005). Most plant demographic studies assume that all plants are detected-i.e., their detection probability is 1 ; however, values $<1$ are widespread in plant demography studies and can lead to biased estimates of population parameters and covariate relationships based upon them (Nichols and Pollock 1995, Kéry and Gregg 2003).

Some plants exhibit prolonged dormancy in which a plant remains alive but invisible

\footnotetext{
${ }^{1}$ Idaho Natural Heritage Program, Idaho Department of Fish and Game, Boise, ID 83707. E-mail: jh.remcat@gmail.com

${ }^{2}$ Department of Fish and Wildlife Sciences, University of Idaho, Moscow, ID 83844.

${ }^{3}$ Present address: 2990 State Hwy. 3, Deary, ID 83823.
} 
belowground for one or more growing seasons (Hutchings 1987, Lesica 1997, Miller et al. 2004, Reintal et al. 2010, Hawryzki et al. 2011). Prolonged dormancy presents problems for estimating demographic parameters because this hidden stage is difficult to measure and to distinguish from plants that have died. All methods to estimate demographic parameters in plants with an unobservable dormant stage rely on the critical assumption that all aboveground plants are detected with certainty (i.e., detection probability equals 1 for all plants except those in the dormant state) (Shefferson et al. 2001, Kéry et al. 2005, Tremblay et al. 2009). Dormancy will be overestimated if this assumption is not met (Shefferson et al. 2001).

Aboveground plants are often undetected due to factors such as life-stage size, surrounding vegetation, herbivory, and observer ability (Shefferson et al. 2001, Kéry and Gregg 2003). Most studies addressing detectability of aboveground plants focus on observer error and life-stage detectability, but few have examined temporal changes in detectability of aboveground plants during one growing season and how time of monitoring can affect demographic estimates.

We examined changes in detectability of aboveground plants over the growing season and their effect on demographic estimates in 2 long-term demographic studies of Spalding's catchfly (Silene spaldingii S.Watson), a Threatened plant exhibiting prolonged dormancy (USFWS 2001, 2007). Most studies and surveys for this species have been conducted at flowering time. A long-term demographic study of Spalding's catchfly conducted at flowering reported up to $50 \%$ annual prolonged dormancy and considered all rosettes to be recruits (Lesica 1997). Other researchers also considered rosettes to be recruits or questioned whether rosettes can be adults (Taylor et al. 2012, Luke 2013). However, our preliminary work with this species showed that several stemmed plants, present early in the growing season, disappeared by flowering (Hill and Gray 2000) and that rosette plants often occurred at flagged locations that supported flowering stemmed plants in previous years (Hill and Weddell 2003). This indicated that all aboveground plants may not be detected at flowering and that rosette plants may be adult plants. Because detection of all aboveground plants is essential for accurate estimates of demographic parameters in plants with an unobservable stage and because the status of the rosette plant was ambiguous, we searched closely for the small, inconspicuous rosette plant at each monitoring period, and we included both an early and late monitoring for each year of our studies.

Objectives of this study were to (1) detect all plants emerging aboveground during a growing season to obtain accurate demographic estimates for this species, (2) clarify the status of the rosette plant, (3) identify and quantify any detectability issues associated with aboveground plant stages, (4) determine the effect of monitoring time on demographic estimates, and (5) provide recommendations for demographic and trend monitoring for this species.

\section{Methods}

\section{Study Species}

Spalding's catchfly (Caryophyllaceae) is a long-lived, herbaceous, perennial plant that occurs in bunchgrass grasslands, sagebrush steppe, and open-canopy pine stands of the inland Pacific Northwest. Aboveground portions of Spalding's catchfly die back completely over the winter and emerge in late May/early June as either a rosette plant, a single-stemmed plant, or a multistemmed plant from a caudex, a persistent stem just beneath the soil surface that surmounts a taproot up to $85 \mathrm{~cm}$ long (Menke 2003). Determination of an individual plant can be difficult due to underground connections of the shoots to the caudex. Flowering occurs from mid-July into October.

\section{Study Area}

Our demographic studies were conducted in the Craig Mountain area of west central Idaho where canyon grasslands cover the slopes and bottoms of the deeply cut valleys of the Snake and Salmon Rivers (Tisdale 1986). Elevational extremes occur within a few miles, ranging from $244 \mathrm{~m}$ at the Snake River to $1586 \mathrm{~m}$ at the summit of Craig Mountain. A Mediterranean climate prevails with mild, wet winters and hot, dry summers.

\section{Field Methods}

We conducted 2 long-term demographic studies, the BLM study (Hill 2012) funded primarily by the Bureau of Land Management 
and the FWS study (Gray et al. 2011, Hill et al. 2014) funded primarily by the U.S. Fish and Wildlife Service; the final results of both studies were summarized in Hill and Garton (2015). We followed individual plants in permanent plots for 10 consecutive years, 2002 2011 for the BLM study and 2004-2013 for the FWS study. To ensure that we were detecting all aboveground plants, we conducted an early and a late monitoring each growing season and did ground-level searches for small rosette plants during each monitoring period. Effects of rodent activity and fire on demography were also examined.

Seventeen monitoring plots, $7 \mathrm{BLM}$ and 10 FWS, were established in known Spalding's catchfly locations; 15 plots were located in the Snake River drainage between $750 \mathrm{~m}$ and $965 \mathrm{~m}$, and 2 plots were located in the Salmon River drainage between $525 \mathrm{~m}$ and $550 \mathrm{~m}$. The BLM plots consisted of a 1-m-wide belt transect varying in length (5-12 m) with the size of the sampled subpopulation; a $50 \times 50-\mathrm{cm}$ frame was used for sampling. The FWS plots consisted of 10-m-wide belt transects, each $10 \mathrm{~m}$ in length, that were adjacent to each other forming a $10 \times 10$-m plot; sampling occurred within each of the 10 transects in the plot. A wildfire burned all 7 BLM plots and 8 of the $10 \mathrm{FWS}$ plots between early and late monitoring in 2007; 1 of the 2 remaining FWS plots also burned just prior to establishment.

Four stage classes of Spalding's catchfly were defined based on differences in size, morphology, reproductive ability, and aboveor belowground status. We identified 3 aboveground classes-rosette (R), single-stem (S), and multistem $(\mathbf{M})$ - and 1 belowground class, dormant (D). The R class produced one to several pairs of leaves with no obvious stem, forming a cluster on the soil surface; it did not bolt into a stemmed plant or flower during the growing season. The $\mathrm{S}$ class produced one stem that either remained vegetative or flowered. The $M$ class produced 2 or more stems and occasionally rosettes; individual stems either remained vegetative or flowered. Most stems of $\mathrm{M}$ plants occurred within a few centimeters of each other, but occasionally they occurred farther apart (up to $8 \mathrm{~cm}$ ), especially in the steep, often terraced slopes of the canyon grasslands. Stemmed stages did not add additional stems over the growing season. These aboveground stage classes were consis- tently recognizable soon after plant emergence and were assigned to all aboveground plants at early monitoring. The $\mathrm{D}$ class produced no aboveground vegetation during a growing season.

Seedlings were distinguished from first-year recruits. Seedlings were very small rosettes $(<1 \mathrm{~cm}$ across) that lay flat on the ground; they supported a pair of distinctive cotyledons and true leaves $(<3-4 \mathrm{~mm})$ without obvious petioles. Because of their small size, seedlings were not consistently observable and were not counted as part of the population or recorded in encounter histories until they returned as first-year recruit rosettes the following year. First-year recruits did not support cotyledons and were larger rosettes with upward-extending leaves that were usually $>1 \mathrm{~cm}$ long with attenuated petioles. Recruits were consistently observable at early monitoring and were assigned to the $\mathrm{R}$ stage class. The presence of a seedling was considered germination and the presence of a first-year recruit was considered recruitment.

Demographic data were recorded for each plant in an encounter history format (e.g., OORRSM0RS0) that shows the aboveground stage classes $(\mathrm{R}, \mathrm{S}$, or $\mathrm{M})$ or the absence of a plant (0) for each year. The presence of an interior zero in the encounter history was assumed to be a D plant. Initial zeros could indicate a dormant plant or pre-germinant status; terminal zeros could be a dormant or dead plant. First-year recruit R plants could not be distinguished morphologically from older, established juvenile or adult $\mathrm{R}$ plants. We therefore made assumptions about recruitment and mortality based on the longest duration of prolonged dormancy known for this species (i.e., 3 years) (Lesica 1997). The criterion for recruitment was the occurrence of a single R plant following at least 3 initial zeros, and the criterion for mortality was at least 3 terminal zeros. Plants were classified as dead in the last year they were observed.

Early monitoring was conducted soon after emergence in early June and late monitoring was conducted at flowering time in late July/early August; systematic ground-level searches were conducted for the 3 aboveground stage classes at both monitoring periods. Two reference coordinates (the linear distance along a transect and the perpendicular distance from the transect), the stage class 
(including number of leaves and longest leaf for $\mathrm{R}$ plants), and the number of stems and rosettes for each plant were recorded at each monitoring period. Reproductive status also was recorded at late monitoring.

Habitat data were collected annually, including percent ground cover affected by rodent activity (runways, holes, diggings). A small mammal census was conducted in late July/early August 2011, and monthly weather data were obtained. Details on methodology and results, including weather and demographic correlations, are provided in Hill (2012), Hill et al. (2014), and Hill and Garton (2015).

\section{Demographic and Statistical Analyses}

The primary demographic analysis we used was the conventional stage-based transition matrix (Leslie 1945, Lefkovitch 1965, Caswell 2001) to obtain proportional transitions between stage classes and to derive demographic estimates by counting the number of transitions into the dead and other stage classes. Transition matrices for each year of the study were developed, as well as a summary stage-based transition matrix that pooled all transitions over the whole data set (Horvitz and Schemske 1995). POPTOOLS (Hood 2010), an add-in Excel program, was used to calculate 2 population parameters: (1) growth rate, the finite rate of population increase $(\lambda)$ that indicates whether a population is increasing, decreasing, or stable; and (2) elasticity, the measure of the proportional sensitivity of the population growth rate to a change in the transition probability in each stage class (de Kroon et al. 1986, Caswell 2001).

Conventional analyses have limitations, however, in determining the fraction dormant, and arbitrary assumptions about the status of the terminal and initial zeros in encounter histories have to be made (Kéry et al. 2005). Therefore, we also included a mark-recapture probabilistic model that is more efficient at capturing the survival and dormancy information in the initial and terminal zeros of an encounter history (Kéry et al. 2005). We used the Cormack-Jolly-Seber (CJS) mark-recapture model (Lebreton et al. 1992) and program MARK (White and Burnham 1999) to estimate survival and the proportion of individuals dormant. For this analysis, encounter histories were converted to a string of zeros and ones with a 1 indicating a plant was present and a 0 indicating a plant was not present in a given year. Rates of survival (S) and detection given survival $(p)$ were calculated. If every plant aboveground was detected, the complement of the detection rate, $1-p$, represented the fraction dormant (Shefferson et al. 2001). Additionally, the complement of the rate of survival, $1-S$, represented the fraction of plants that had died. The CJS mark-recapture models used the Akaike information criterion (AIC) to determine the best model that explains the variation in the data while using the fewest parameters.

For statistical analyses, we used a $t$ test (Zar 1984), $P \leq 0.05$, to test the differences in means. For the measure of variability associated with means, we used the standard deviation. We used the CORREL function in Microsoft Excel 2000 to compute the Pearson correlation coefficient and to determine relationships between demographic and environmental factors.

\section{Results}

\section{Plants and Aboveground Plant-Years}

A total of 947 individual plants (152 [BLM] and 795 [FWS]) were documented in both studies over the study periods. All of these plants were identified at early monitoring; no additional plants were identified at late monitoring in either study. Many plants disappeared or became undetectable or unidentifiable over the growing season. If we had monitored only at flowering time, considerably fewer plants - 567 individual plants (120 [BLM] and 447 [FWS])—would have been detected, an underestimation of the number of plants actually in the plots by $40 \%$. Aboveground plant-years (presence of an aboveground plant in a given year) totaled 3770 (699 $[\mathrm{BLM}]$ and 3071 [FWS]); of these, $99.9 \%$ were seen at early monitoring. Four aboveground plant-years in the FWS study were not seen early, but were seen late; it is unclear whether they were present early but not detected or whether they emerged after early monitoring. Late monitoring indicated considerably fewer aboveground plant-years, totaling 1969 (377 [BLM] and 1592 [FWS]), an underestimation of aboveground plant-years actually documented in the studies by $48 \%$.

\section{Detection Probability}

Almost all (99.9\%) of the aboveground plants were present and detected at early 

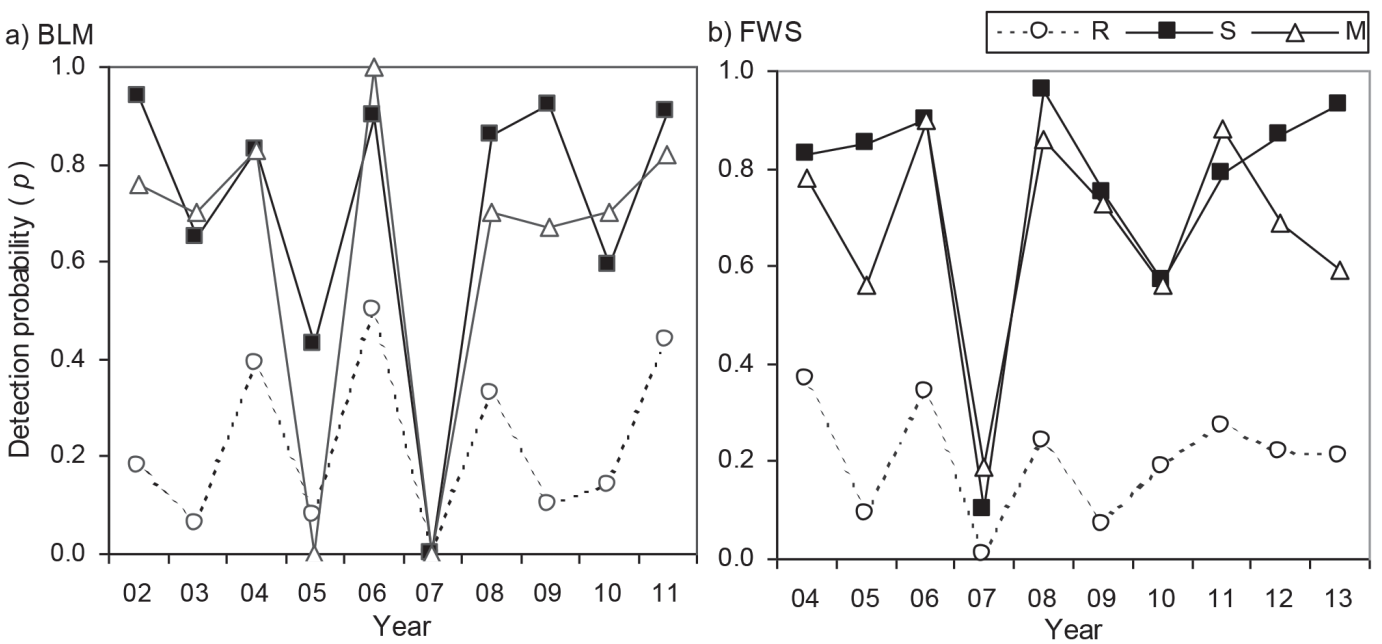

Fig. 1. Annual detection probability ( $p$ ) of aboveground stage classes at flowering time: a, BLM study, 2002-2011; b, FWS study, 2004-2013. Annual detection probability of aboveground stage classes at early monitoring $=1$.

monitoring, giving each aboveground stage class a detection probability $(p)$ of $\sim 1.0$ at early monitoring. However, detectability of aboveground stage classes decreased over the growing season. Of the plants present at early monitoring, $48 \%(46.4 \% \pm 25.5 \%[\mathrm{BLM}]$ and $48.0 \% \pm 18.8 \%$ [FWS]) disappeared, became undetectable, or were not identifiable to stage class by flowering time. The wildfire that burned plants just prior to late monitoring in 2007 was responsible for $4 \%-5 \%$ of this loss of detectability. The $\mathrm{R}$ stage was disproportionately affected; $80 \%$ (BLM) and $81 \%$ (FWS) of $\mathrm{R}$ plants either disappeared or became undetectable/unidentifiable by flowering. Plants in the $\mathrm{R}$ stage were small and were located on the ground surface below the bunchgrass canopy. Some plants only had 1 or 2 leaves. $\mathrm{R}$ stage plants were also ephemeral-present soon after emergence, not increasing in size, nonreproductive over the growing season, and usually senescent and/or disappeared by flowering. Detectability of stemmed stages also declined considerably by flowering time: $30 \%$ (BLM) and $25 \%$ (FWS) of S plants disappeared and $31 \%(\mathrm{BLM})$ and $30 \%$ (FWS) of $\mathrm{M}$ plants either disappeared or were unidentifiable as M plants because they lost a $\operatorname{stem}(\mathrm{s})$ over the growing season and appeared to be $S$ plants at flowering. Detection probability of aboveground stage classes at flowering time was considerably reduced compared to that of $\sim 1.0$ at early monitoring, and it also showed high annual variability (Fig. 1). The mean annual stage class detection probabilities at flowering were as follows: $0.22 \pm 0.17$ for the R stage, $0.70 \pm 0.28$ for the S stage, and $0.62 \pm$ 0.34 for the M stage (BLM) and $0.20 \pm 0.12$ for the $\mathrm{R}$ stage, $0.76 \pm 0.26$ for the $\mathrm{S}$ stage, and $0.67 \pm 0.21$ for the M stage (FWS).

\section{Status of the Rosette Plant}

Our preliminary studies with this species documented rosette plants at several flagged locations that had supported flowering stemmed plants in previous years (Hill and Gray 2000). Careful, nondestructive removal and replacement of soil around the caudex of several of these rosette plants revealed their connection to large, mature caudices (Hill and Weddell 2003). These rosettes were obviously not recruits but represented adults that had retrogressed from flowering stemmed plants. Ten years of demographic monitoring in both studies confirmed these observations. Over the study periods, $32 \%$ (BLM) and $40 \%(\mathrm{FWS})$ of plants emerged aboveground in the $\mathrm{R}$ stage; however, their maturity status could not be determined from their appearance. No diagnostic morphological feature could be identified to distinguish first-year recruits (had been seedlings the previous year), juveniles (had not reproduced in previous years), and adults (had reproduced as stemmed plants in previous years). Over the study periods, encounter histories showed that (1) 3\% (BLM) and 24\% 
(FWS) of R plants were first-year recruits, (2) $3 \%$ (BLM) and $17 \%$ (FWS) were juveniles, (3) $30 \%$ (BLM) and $16 \%$ (FWS) were adults, and (4) $41 \%$ (BLM) and 27\% (FWS) were either juveniles or adults, but not recruits because they had been $\mathrm{R}$ plants in the previous year. Most R plants, 74\% (BLM) and 60\% (FWS), were established plants present in previous years as either $\mathrm{D}, \mathrm{R}, \mathrm{S}$, or M plants rather than recruits. The status of the remaining 23\% (BLM) and 16\% (FWS) R plants could not be determined because it was unknown if they were present or reproduced before the studies began.

\section{Demographic Estimates}

Almost all (99.9\%) of the aboveground plants were present and detected at early monitoring, meeting the critical assumption that all aboveground plants must be detected to obtain accurate demographic estimates for this species with a dormant stage. The demographic estimates that follow, therefore, were based on the early encounter histories. We also present demographic estimates based only on our late encounter histories ("Late Estimates") to identify and quantify the bias we would have obtained if we had monitored only at flowering time when $48 \%$ of the aboveground plant-years had disappeared or become undetectable/ unidentifiable. The absence of late data in 2007 due to the wildfire presented problems in applying our criteria for recruitment, dormancy, and mortality, as well as in determining other demographic estimates for the late data set. We therefore estimated late data for 2007. We had collected early monitoring data for 2007 prior to the fire and knew what plants were present aboveground that year. We estimated which of these plants would likely still be present, detectable, and identifiable at late monitoring using a random numbers generator and the average detection probability for each aboveground stage class at flowering.

TOTAL PLANT-YEARS. - The number of plantyears and proportions in each of the 4 stage classes (including the portion of the $\mathrm{R}$ stage that were first-year recruits) varied annually for both early and late monitoring (Fig. 2). The BLM study showed a sharp decline between 2003 and 2004, with further decline at the end of the study. Low levels of recruitment in this study did little to offset these declines. In the FWS study, annual plant-years were more stable and recruitment was higher, especially at the end of the study, resulting in increasing levels of juvenile $R$ plants and total plantyears in each of the last 3 years of the study. Dormant plant-years for both studies totaled 250 (44 [BLM] and 206 [FWS]). Based on the middle 8 years of the studies, plants spent $42 \%$ (BLM) and $38 \%$ (FWS) of their lives in the S stage, 31\% (BLM) and 36\% (FWS) in the R stage, $19 \%$ (BLM) and 18\% (FWS) in the M stage, and $8 \%$ (both studies) in the D stage.

Late estimates. Both studies indicated much lower proportions of the $\mathrm{R}$ stage and higher proportions of the $\mathrm{D}$ stage. Dormant plantyears were considerably overestimated, totaling 505 (122 [BLM] and 383 [FWS]), over twice the dormant plant-years at early monitoring. Late-monitoring stage class distribution was $45 \%$ (BLM) and 48\% (FWS) in the S stage, $28 \%$ (BLM) and $21 \%$ (FWS) in the D stage, $18 \%$ (BLM) and $20 \%$ (FWS) in the M stage, and 9\% (BLM) and $11 \%$ (FWS) in the $\mathrm{R}$ stage. This distribution underestimated the $\mathrm{R}$ stage and overestimated the $\mathrm{D}$ stage by factors of approximately 3 . The $\mathrm{S}$ stage was somewhat overestimated, especially in the FWS study. A total of $125 \mathrm{M}$ plants (24 [BLM] and $101[\mathrm{FWS}]$ ) were unidentifiable; they had lost a stem(s) and appeared to be S plants at late monitoring. The high levels of recruitment and subsequent increases in juvenile $\mathrm{R}$ plants and total plant-years in the last 3 years of the FWS study were substantially underestimated, giving the impression that the population was declining the last 3 years when it was actually increasing.

Recruitment.-A total of 304 recruitments (6 [BLM] and 298 [FWS]) were documented. Based on the 7 years for which it could be determined, annual recruitment rate varied from $0 \%$ to $5.8 \%$ with a mean rate of $1.3 \% \pm 2.1 \%$ in the BLM study and from $2.6 \%$ to $25.7 \%$ with a mean rate of $12.4 \% \pm 9.4 \%$ in the FWS study. Two distinct recruitment periods occurred in the FWS study: a low period from 2007 to 2010 averaging $5.2 \%$ annually and a high period from 2011 to 2013 averaging $22.1 \%$ annually. All first-year recruits emerged in the R stage class, and they survived to the following year 83\% (BLM) and 66\% (FWS) of the time. Juvenile periods, the number of years that first-year recruits remained in the $\mathrm{R}$ stage class before becoming reproductive $\mathrm{S}$ or $\mathrm{M}$ plants, were 6 years \pm 1.4 years $(\mathrm{BLM})$ and 

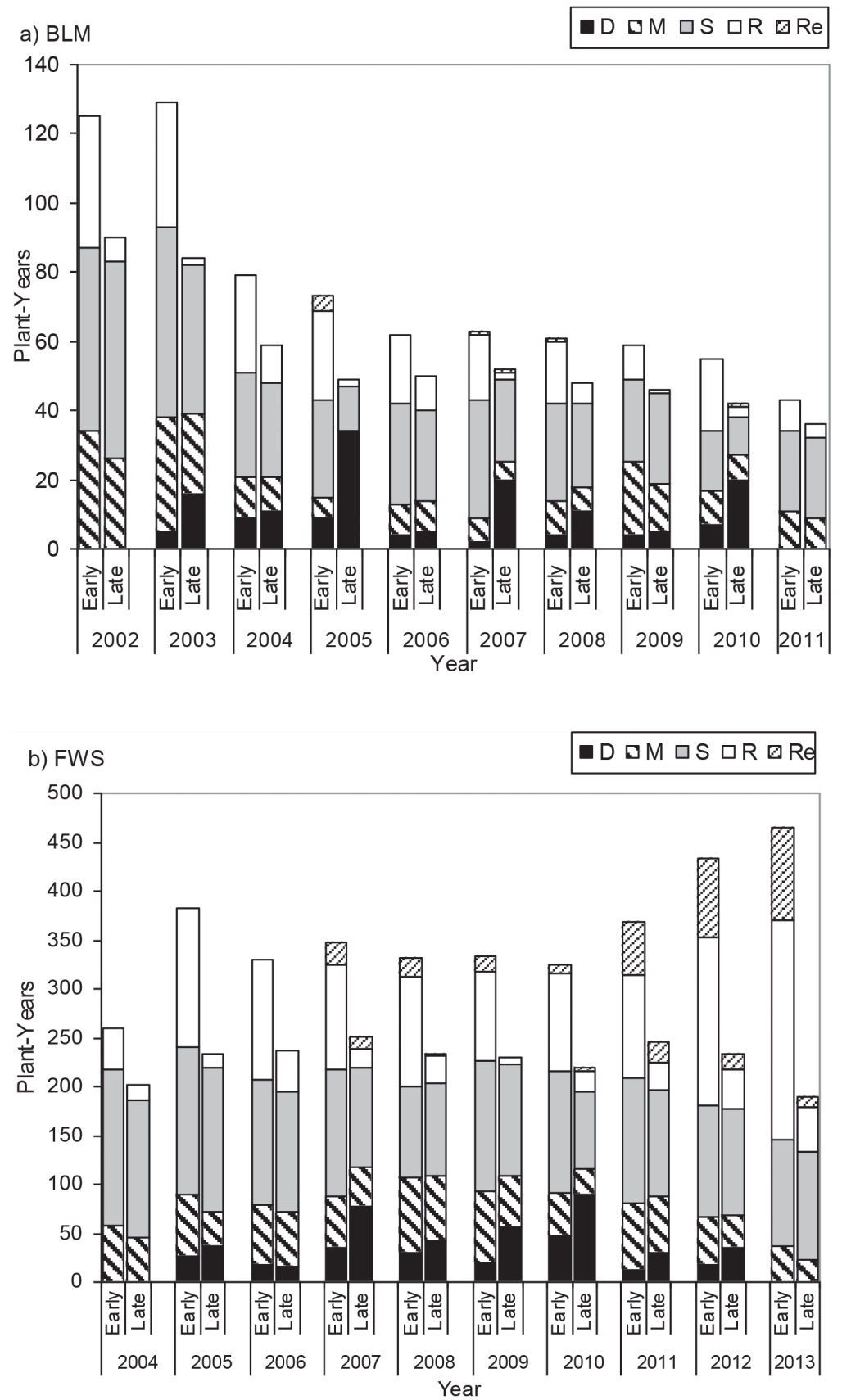

Fig. 2. Annual number of plant-years and stage class distribution at early and late monitoring (including the portion of the R stage class that were first-year recruits [Re]): a, BLM study, 2002-2011; b, FWS study, 2004-2013. In both studies, Re plants could not be determined in the first 3 years and D plants could not be determined in the first and last years. $\mathrm{D}=$ dormant, $\mathrm{R}=$ rosette, $\mathrm{S}=$ single-stem, $\mathrm{M}=$ multistem.

4.3 years \pm 1.8 years $(\mathrm{FWS})$. We only observed seedlings in the last 3 years of the FWS study. They often occurred in clusters in close proximity to each other. Most disappeared by flow- ering time, but the few that were still alive had grown little, if any, and had retained their senescent cotyledons. Of the 189 seedlings observed at early monitoring in the FWS 
study in 2012 , only $10 \%$ returned the following year as first-year recruits. Some individual recruits survived within $2-3 \mathrm{~cm}$ of each other for several years.

A Montana demography study reported that fire increases recruitment by reducing litter (Lesica 1999). However, in both of our studies recruitment did not increase in the 3 years following the 2007 wildfire, even though litter depth was at its lowest and bare ground at its highest levels. The fire caused high mortality of mosses and lichens. No recruitment occurred in the remainder of the BLM study that ended in 2011. The FWS study continued through 2013 and showed a large increase in recruitment the fourth year after the fire as bare ground decreased, litter depth increased to preburn levels, and colonizing mosses started to establish. At early monitoring in 2012 and 2013, seedlings were often observed in close association with moss, and several were still alive at late monitoring despite no precipitation and the hottest temperatures recorded during the studies. We often observed early morning dew on mosses, and that dew may have provided associated seedlings the moisture needed to survive this extreme period. Strong positive correlations were demonstrated between moss and lichen cover and recruitment, +0.98, and ground litter depth and recruitment, +0.96 , during the 6 years following the fire in the FWS study.

Late estimates. Late monitoring indicated considerably fewer recruitments, 2 (BLM) and 68 (FWS), than those that had actually occurred at early monitoring. All 6 of the early BLM recruitments and $88 \%$ of the 298 early FWS recruitments were missed by late monitoring. Both of the late BLM recruitments were false; they had not actually occurred at early monitoring. Of the 68 (FWS) late recruitments, $36(53 \%)$ were correct and 32 (47\%) were false. No seedlings (germination) were observed.

Prolonged Dormancy.-Dormant plantyears (presence of a dormant plant in a given year) were 44 (BLM) and 206 (FWS). Approximately $20 \%$ of plants in both studies exhibited prolonged dormancy. Most had 1 episode of dormancy, but some had 2 or 3 episodes. In the BLM study, 33 (22\%) of the total 152 plants demonstrated a total of 41 dormant episodes. Of these episodes, $93 \%$ were 1-year dormancies and $7 \%$ were 2 -year dormancies, representing a mean dormancy duration of 1.07 years. In the FWS study, 157 (20\%) of the total 795 plants demonstrated a total of 186 dormant episodes. Of these episodes, $90 \%$ were 1 -year dormancies, $10 \%$ were 2 -year dormancies, and $<1 \%$ were 3 -year dormancies, representing a mean dormancy duration of 1.11 years.

Annual dormancy rates (and mortality rates) were calculated using both conventional analysis (restricted to the middle 8 years of the studies) and CJS mark-recapture analysis (utilized the entire 10-year data set). For the CJS mark-recapture analysis we ran 3 models, the full model with both $\mathrm{S}$ and $p$ varying by time $\left\{\mathrm{S}_{\text {time }}, p_{\text {time }}\right\}$, and 2 reduced models, with either survival $(\mathrm{S})$ constant or detection $(p)$ constant but the other parameter varying by time. The best model to explain the variability in the data for the BLM study was $\{\mathrm{S}(\mathrm{t}) p$ (constant $)\}$, and the best model for the FWS study was $\{\mathrm{S}(\mathrm{t}) p(\mathrm{t})\}$ (Table 1 ). To obtain estimates of annual rates for both mortality $(\mathrm{S}-1)$ and dormancy $(p-1)$, we used the $\{\mathrm{S}(\mathrm{t}) p(\mathrm{t})\}$ model for both studies. In general, conventional and CJS methods corroborated each other (Table 2); however, the markrecapture estimates are likely more accurate because they utilized the entire 10-year data sets. Annual rates of dormancy determined by mark-recapture analysis varied from 3\% to $16 \%(\mathrm{BLM})$ and from $6 \%$ to $19 \%$ (FWS) with a mean annual dormancy rate of $9.7 \%$ (BLM) and $11.0 \%$ (FWS); these values were slightly higher than those determined by conventional analysis.

Late estimates. Late monitoring indicated considerably more dormant plant-years, much higher proportions of plants exhibiting dormancy, more dormant episodes, longer duration of dormancy, much higher mean annual dormancy rates, and much greater annual variation in dormancy rates. Late monitoring indicated considerably more dormant plantyears, 122 (BLM) and 383 (FWS), than those actually present at early monitoring. Most of these late dormant plant-years, 72\% (BLM) and $64 \%$ (FWS), were false; they were not present at early monitoring. Of the dormant plant-years actually present at early monitoring, 20\% (BLM) and 33\% (FWS) were missed by late monitoring. In the BLM study, dormancy was indicated in $46 \%$ of plants $(55$ of 120) with a total of 95 dormant episodes. 
TABLE 1. CJS model selection for survival $(S)$ and detection probability $(p)$ and estimates for best-fit models for the BLM and FWS studies. The best model is indicated in bold type. $(\mathrm{t})=$ time varying; Num. par. $=$ number of estimable parameters.

\begin{tabular}{|c|c|c|c|c|c|c|}
\hline Model & $\mathrm{AIC}_{c}$ & $\Delta \mathrm{AIC}_{c}$ & $\begin{array}{c}\mathrm{AIC}_{c} \\
\text { weights }\end{array}$ & $\begin{array}{c}\text { Model } \\
\text { likelihood }\end{array}$ & Num. par. & Deviance \\
\hline \multicolumn{7}{|l|}{ BLM } \\
\hline$\{\mathrm{S}(\mathrm{t}) \boldsymbol{p}($ constant $)\}$ & 823.7 & 0.00 & 0.89 & 1.00 & 10 & 142.5 \\
\hline$\{\mathrm{S}(\mathrm{t}) p(\mathrm{t})\}$ & 827.8 & 4.11 & 0.11 & 0.13 & 17 & 132.0 \\
\hline$\{\mathrm{S}($ constant $) p(\mathrm{t})\}$ & 897.2 & 73.49 & 0.00 & 0.00 & 10 & 216.0 \\
\hline \multicolumn{7}{|l|}{ FWS } \\
\hline$\{\mathbf{S}(\mathbf{t}) \boldsymbol{p}(\mathrm{t})\}$ & 3533.5 & 0.00 & 1.00 & 1.00 & 17 & 436.5 \\
\hline$\{\mathrm{S}(\mathrm{t}) p($ constant $)\}$ & 3556.0 & 22.44 & 0.00 & 0.00 & 10 & 473.1 \\
\hline$\{\mathrm{S}($ constant $) p(\mathrm{t})\}$ & 3695.8 & 162.24 & 0.00 & 0.00 & 10 & 612.9 \\
\hline
\end{tabular}

TABLE 2. Comparison of annual mortality and dormancy rates calculated by conventional and mark-recapture CJS analyses, model $\{\mathrm{S}(\mathrm{t}) p(\mathrm{t})\}$, for the BLM and FWS studies.

\begin{tabular}{|c|c|c|c|c|c|}
\hline \multirow[b]{2}{*}{ Study } & \multirow[b]{2}{*}{ Year } & \multicolumn{2}{|c|}{ Annual mortality rates (\%) } & \multicolumn{2}{|c|}{ Annual dormancy rates (\%) } \\
\hline & & Conventional & Mark-recapture & Conventional & Mark-recapture \\
\hline \multirow[t]{9}{*}{$\overline{B L M}$} & 2003 & 41.1 & 41.1 & 3.9 & 7.6 \\
\hline & 2004 & 17.7 & 18.5 & 11.4 & 14.4 \\
\hline & 2005 & 10.1 & 11.6 & 13.0 & 15.4 \\
\hline & 2006 & 1.6 & 1.6 & 6.5 & 6.6 \\
\hline & 2007 & 4.8 & 4.9 & 3.2 & 3.4 \\
\hline & 2008 & 1.7 & 1.3 & 6.7 & 6.9 \\
\hline & 2009 & - & 3.3 & 6.8 & 7.3 \\
\hline & 2010 & - & 13.4 & 12.7 & 16.3 \\
\hline & MEAN & 12.8 & 12.0 & 8.0 & 9.7 \\
\hline \multirow[t]{9}{*}{ FWS } & 2005 & 32.2 & 34.1 & 7.1 & 16.5 \\
\hline & 2006 & 11.6 & 10.9 & 5.2 & 7.4 \\
\hline & 2007 & 9.9 & 10.6 & 10.8 & 13.3 \\
\hline & 2008 & 4.8 & 5.0 & 9.3 & 10.4 \\
\hline & 2009 & 4.1 & 0.2 & 6.3 & 7.0 \\
\hline & 2010 & 18.7 & 21.2 & 14.9 & 18.9 \\
\hline & 2011 & - & 13.3 & 4.1 & 5.9 \\
\hline & 2012 & - & 20.3 & 5.1 & 8.4 \\
\hline & MEAN & 13.6 & 14.5 & 7.8 & 11.0 \\
\hline
\end{tabular}

Of these episodes, $78 \%$ were 1-year dormancies, $16 \%$ were 2 -year dormancies, and $6 \%$ were 3-year dormancies, representing a mean dormancy duration of 1.28 years. In the FWS study, dormancy was indicated in $44 \%$ of plants (194 plants of 439 plants) with a total of 292 dormant episodes. Of these episodes, $82 \%$ were 1-year dormancies; $11 \%$ were 2 -year dormancies, $5 \%$ were 3 -year dormancies, $1 \%$ were 4 -year dormancies, and $1 \%$ were 5 -year dormancies, representing a mean dormancy duration of 1.30 years. Mean annual dormancy rates were significantly greater, 29\% (BLM) and $21 \%$ (FWS), and showed much higher annual variation, $11 \%-70 \%(\mathrm{BLM})$ and $7 \%-$ $42 \%$ (FWS), at late monitoring. In the BLM study, early monitoring in 2005 documented 60 aboveground plants and a 13\% dormancy rate. Following one of the hottest, driest growing seasons, 44 of these plants disappeared or were undetectable by late monitoring. If we had only sampled at flowering time these false absences would have been misclassified as dormancies, indicating a considerably overestimated dormancy rate of $70 \%$.

MorTaLITY.-High mortality occurred in both studies coinciding with 2 episodes of high rodent activity. During the episodes, considerable damage occurred to the habitat (numerous runways denuded of vegetation, shallow diggings, small holes up to $10 \mathrm{~cm}$ deep) and to Spalding's catchfly plants (severed stems occasionally pulled down into rodent holes, holes at known plant sites and plant caudices absent, runways ending at plant sites with damaged or absent plants). Spalding's catchfly 
TABLE 3. Summary stage-based transition matrix and mean elasticities (in parentheses) for the BLM study (2003-2010) and the FWS study (2005-2012). Bolded numbers indicate most important transition probabilities and elasticities. Survival (sum of transition probabilities in each stage class column) and total elasticity (sum of elasticities in each stage class column) for each stage class $(\mathrm{D}=$ dormant, $\mathrm{R}=$ rosette, $\mathrm{S}=$ single-stem, $\mathrm{M}=$ multistem) are presented in the summation row at the bottom of each matrix. $(\lambda=$ population growth rate; Surv. $=$ survival; $[\mathrm{Sum}]=$ sum of elasticities $)$.

\begin{tabular}{|c|c|c|c|c|}
\hline & \multicolumn{4}{|c|}{ From } \\
\hline & $\mathrm{D}$ & $\mathrm{R}$ & S & M \\
\hline \multicolumn{5}{|l|}{ To } \\
\hline $\mathrm{D}$ & $0.08(0.01)$ & $0.06(0.03)$ & $0.10(0.06)$ & $0.04(0.01)$ \\
\hline $\mathrm{R}$ & $0.43(0.05)$ & $0.55(0.22)$ & $0.09(0.05)$ & $0.09(0.02)$ \\
\hline $\mathrm{S}$ & $0.33(0.03)$ & $0.19(0.07)$ & $0.53(0.27)$ & $0.28(0.05)$ \\
\hline M & $0.16(0.01)$ & $0.06(0.02)$ & $0.13(0.05)$ & $0.31(0.05)$ \\
\hline \multirow[t]{4}{*}{ Surv. [Sum] } & $1.00[0.10]$ & $0.86[\mathbf{0 . 3 4}]$ & $0.85[\mathbf{0 . 4 3}]$ & $0.72[0.13]$ \\
\hline & & & & $\lambda=0.85$ \\
\hline & \multicolumn{4}{|c|}{ From } \\
\hline & $\mathrm{D}$ & $\mathrm{R}$ & S & M \\
\hline \multicolumn{5}{|l|}{ To } \\
\hline $\mathrm{D}$ & $0.11(0.01)$ & $0.05(0.01)$ & $0.10(0.06)$ & $0.06(0.02)$ \\
\hline $\mathrm{R}$ & $0.27(0.02)$ & $0.54(0.10)$ & $0.07(0.03)$ & $0.04(0.01)$ \\
\hline S & $0.41(0.05)$ & $0.16(0.04)$ & $0.56(0.30)$ & $0.29(0.08)$ \\
\hline M & $0.21(0.02)$ & $0.04(0.01)$ & $0.14(0.08)$ & $0.51(0.16)$ \\
\hline \multirow[t]{2}{*}{ Surv. [Sum] } & $1.00[0.10]$ & $0.79[0.16]$ & $0.87[\mathbf{0 . 4 7}]$ & $0.89[\mathbf{0 . 2 7}]$ \\
\hline & & & & $\lambda=0.87$ \\
\hline
\end{tabular}

plants appeared to have been targeted by rodents because similar damage was not observed on associated forbs and because plant deaths occurred at the onset of both episodes, considerably sooner than the observation of highest rodent activity levels in habitat microplots. Rodent traps set up at late monitoring in 2011 captured 8 montane voles (Microtus montanus) and 23 deer mice (Peromyscus maniculatus). Based on our mortality criterion for Spalding's catchfly, 93 deaths (BLM) and 303 deaths (FWS) occurred in the first 7 years of the studies, representing an overall mortality rate for this period of $61 \%(\mathrm{BLM})$ and $54 \%$ (FWS).

Annual mortality rates showed similar results for both conventional analysis and CJS mark-recapture analysis (Table 2). The mortalities occurred at the onset of the 2 episodes of high rodent activity in late 2003 and in 2010; few deaths occurred when rodent activity ceased between episodes from 2006 through 2009. The CJS mark-recapture analysis was particularly helpful in the BLM study to show the mortality increases with the second episode of rodent activity. The mortality criterion we used with the conventional transition matrix analysis was limited to the first 7 years of the study and therefore could not reveal the mortalities that occurred in the last 3 years of the studies. Increased mortality in the FWS study in 2012 may be related to recruitment increases at the end of this study and subsequent increases in juvenile mortality.

Late estimates. Late monitoring indicated fewer mortalities, 72 (BLM) and 186 (FWS), than those that had actually occurred at early monitoring; $27 \%$ of the 93 early mortalities (BLM) and $44 \%$ of the 303 early mortalities (FWS) were missed by late monitoring. Of the 72 late BLM mortalities, $53(74 \%)$ were correct and $19(26 \%)$ were false (they had not actually occurred). Of the 186 late FWS mortalities, $134(72 \%)$ were correct and $52(28 \%)$ were false.

Transition Probability, Elasticity, Growth Rate.-Summary stage-based transition matrices (based on the middle 8 years of the studies) showed all possible transitions that occurred between the 4 stage classes in both studies (Table 3). Transitions that had the greatest effect on population growth (those with highest elasticities) were stasis transitions of aboveground stage classes; plants tended to stay in the same aboveground stages from year to year. Aboveground stasis transitions represented 54\% (BLM) and 56\% (FWS) of proportional effects on population growth. Stasis 


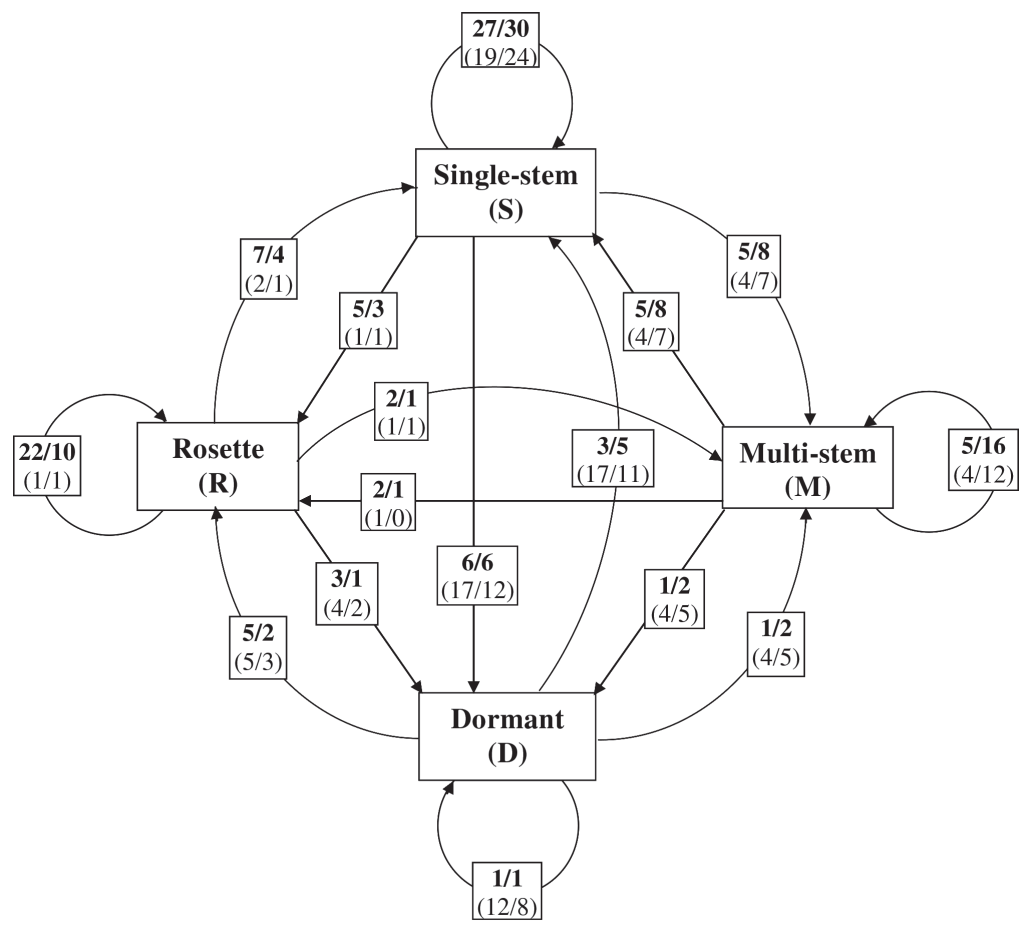

Fig. 3. Life cycle diagram. Values represent elasticity proportions (elasticity probabilities $\times 100$ ) of each stage transition at early monitoring (bolded numbers; late monitoring values $=$ unbolded numbers in parentheses). BLM values are on the left and FWS values are on the right of each slash. Circles = stasis transitions; curved lines = growth transitions; straight lines $=$ retrogression transitions. Numbers for each monitoring period total 100 for each study.

transitions in the D class represented only $1 \%$ of proportional effects. The remaining transitions represented retrogression and growth transitions divided in relatively equal proportions in both studies. A life cycle diagram (Fig. 3) shows transitions between stage classes and elasticity proportions for stasis, growth, and retrogression transitions at early monitoring (late monitoring results are also presented). Total elasticity, the sum of elasticities for a stage class column (Table 3), was highest for the $\mathrm{S}$ class and lowest for the $\mathrm{D}$ class in both studies. The primary differences between the studies were the greater importance of the $R$ stage class in the BLM study and the greater importance of the M class in the FWS study. Annual population growth rate $(\lambda)$ was much lower at the beginning and end of the studies, corresponding to the periods of highest mortality. Both studies showed a strong negative correlation between annual growth rates and mortality rates, -0.90 (BLM) and -0.86 (FWS). Overall growth rates for each study were 0.85 (BLM) and 0.87 (FWS).
Late estimates. Stasis transitions for aboveground plants showed considerably lower proportional effects on population growth, $24 \%$ (BLM) and 37\% (FWS), due primarily to the much lower effect of the R-to-R stasis transition. The D-to-D stasis transition indicated much higher proportional effect on the population, 12\% (BLM) and 8\% (FWS). Transitions involving the D class were considerably overestimated, and transitions involving the $\mathrm{R}$ class were considerably underestimated. As in early monitoring, the S class had the highest total elasticity, but the D class was second in total elasticity and the R class had the lowest total elasticity. Growth rates were similar to those based on early monitoring, 0.84 (BLM) and 0.88 (FWS).

Response to Environmental Stress.Annual transition matrices in both studies showed that retrogression of the stemmed plants $(\mathrm{S}+\mathrm{M})$ to the $\mathrm{R}$ stage increased during periods of environmental stress (i.e., high rodent activity and fire) and decreased when these disturbances were removed. Dormancy 
and mortality increased during the 2 episodes of high rodent activity and decreased when this activity ceased between the episodes (Table 2). Annual total elasticity varied for the 3 aboveground stage classes and demonstrated a trend of decreasing $\mathrm{S}$ class dominance and increasing $\mathrm{R}$ class dominance during rodent activity and the 2007 wildfire. Annual growth rates were lowest in both studies during episodes of rodent activity. Annual survival probability of the $\mathrm{R}$ stage was higher than that of both the $\mathrm{S}$ and $\mathrm{M}$ stages in the first episode of the BLM study and the second episode of the FWS study, suggesting that rodents targeted larger plants.

Late estimates. All transitions involving the $\mathrm{R}$ stage were considerably underestimated; increases and decreases in the $S$ and $\mathrm{M}$ to $\mathrm{R}$ retrogressions associated with disturbance were not as consistent or pronounced. The trend of decreasing $\mathrm{S}$ and increasing $\mathrm{R}$ total elasticities during environmental stress was not indicated, nor was there a higher survival rate of the $\mathrm{R}$ stage compared to that of the $\mathrm{S}$ and $\mathrm{M}$ stages during episodes of rodent activity.

\section{Discussion}

\section{Detectability and Demographic Estimates}

Spalding's catchfly is a challenging species to monitor. It demonstrates both stage-dependent and time-dependent detectability. The D stage is invisible belowground, the $\mathrm{R}$ stage is small and inconspicuous, and all 3 aboveground stages can disappear or become undetectable over the growing season, especially the ephemeral $\mathrm{R}$ stage. To determine the fraction of dormant plants invisible belowground, it is essential that all aboveground plants, including those that are small and inconspicuous or those that are only visible for a brief period of time, be detected with certainty (Kéry et al. 2005). Dormancy will be overestimated if this assumption is not met (Shefferson et al. 2001). Early and late monitoring with ground-level searches in our studies verified that almost all (99.9\%) aboveground plants were present, detected, and identifiable to stage at early monitoring and that detection probability for all 3 aboveground stages was - 1.0. Detecting over 99\% of aboveground plants enabled us to obtain not only the fraction of dormant plants but also the total num- ber of plants in our plots, which was essential for determining other demographic estimates, including percentages (percent flowering, percent senescent, stage class distribution, etc.) and rates (recruitment, dormancy, mortality). The ground-level searches eliminated stage-dependent detectability problems associated with the R stage, and early monitoring eliminated the time-dependent detectability problems of aboveground stages that disappeared or became undetectable or unidentifiable over the growing season. The early and late monitoring periods allowed us to identify and quantify detection problems associated with aboveground stages and to determine how time of monitoring affected demographic estimates. Late monitoring occurred after many plants in each aboveground stage class had disappeared or become undetectable, and detection probabilities were much less than 1.0 for all aboveground stages. Monitoring only at flowering time in our studies would have resulted in considerably biased demographic estimates, including (1) underestimation of plants by $40 \%$ and aboveground plantyears by 48\%; (2) 64\%-72\% false dormant plant-years and overestimation of prolonged dormancy by 2-3 times; (3) overrepresentation of the D stage and the role of dormancy in this species; (4) underrepresentation of the $\mathrm{R}$ stage and its importance for survival; (5) many missed recruitments; (6) inaccurate determinations of recruitment, dormancy, and mortality; and (7) indications that the FWS population was declining when it was actually increasing.

It is reasonable to expect a decrease in detectability of aboveground plants in this species by flowering time. Climate diagrams from all of the physiographic regions where Spalding's catchfly occurs show a pronounced summer drought period (Hill and Gray 2004). Many associated forb species bloom early and stop growing during the summer months (Daubenmire 1970), but this species is an exception. It has a long growing season and represents one of the few late-blooming species that is actively growing and reproducing during the summer, making it a target for herbivory. Its long taproot likely enables access to deep soil water resources permitting survival; however, aboveground plant tissue is subject to desiccation, herbivory, and fire damage that reduce detectability. 


\section{New Life History and \\ Demographic Information}

Our studies provided ample new information regarding the life history and population dynamics of Spalding's catchfly. Very similar results were obtained in both studies even though the studies differed in sites, plot design, time periods, number of plants tracked, and primary observers. The 2 basic methods shared by both studies were early and late monitoring and ground-level searches at both monitoring periods. This methodology was instrumental in discovering the new information, much of which would not have been revealed if we had only monitored at flowering time and not conducted ground-level searches. Our results differed considerably from 2 previous studies, a long-term demography study in Montana that monitored at flowering (Lesica 1997, 1999, Lesica and Crone 2007) and a 5-year demography and phenology study in northeastern Oregon (Taylor et al. 2012) that monitored stemmed plants weekly through the growing season but did not include ground-level searches for rosettes at each monitoring period.

Status of the Rosette Plant.-There has been considerable controversy among researchers over the status of the rosette plant in this species. In the Montana and Oregon demography studies, few rosettes were detected and all were considered recruits (Lesica 1997, 1999, Lesica and Crone 2007, Taylor et al. 2012). Other studies have questioned whether rosettes can be adult plants (Luke 2013). For effective management and conservation of this rare species, it is vitally important to determine whether a rosette plant is a recruit or not. The early monitoring and ground-level searches in our studies enabled us to identify the $\mathrm{R}$ stage class as a previously undescribed major vegetative stage class for this species and to determine its importance to the population dynamics of the species. Plants spent about one-third of their lives in the $\mathrm{R}$ stage class. Some were first-year recruits, but the large majority were established plants, either juveniles or adults, that had been present in previous years as $\mathrm{R}, \mathrm{S}, \mathrm{M}$, or $\mathrm{D}$ plants. In the Montana study rosettes were not observed to transition to stemmed plants, only to other rosette or dormant plants, and no stemmed plants were observed to retrogress to rosettes (Lesica 1997, 1999, Lesica and Crone 2007).
In contrast, our results showed that $\mathrm{R}$ plants transitioned to larger reproductive $\mathrm{S}$ and $\mathrm{M}$ plants 25\% (BLM) and 20\% (FWS) of the time and that $\mathrm{S}$ and $\mathrm{M}$ plants retrogressed to $\mathrm{R}$ plants 18\% (BLM) and 11\% (FWS) of the time. Elasticity analysis showed that the $\mathrm{R}$ stage class is important for plant fitness and population growth. The high survival rate of the $R$ stage class during rodent activity and the increases in retrogression from the stemmed stage classes to the $\mathrm{R}$ stage class during both rodent activity and fire indicate its survival value for this species. Larger $\mathrm{R}$ plants with leaves up to $10 \mathrm{~cm}$ in length tended to persist longer into the growing season than smaller $\mathrm{R}$ plants and likely provided considerable resource acquisition through photosynthesis.

Other demography studies that included early monitoring have reported even higher numbers of $\mathrm{R}$ plants and their tendency to disappear by flowering. Early monitoring in a southeastern Washington study reported 23\%$30 \%$ R plants annually from 2009 to 2011 (Clark 2010); however, monitoring only at flowering in 2012 discovered no rosette plants (Laura Heinse, Washington State University, personal communication). Monitoring for the FWS study was conducted only at flowering time in 2002 and 2003, and only a few R plants were detected (Gray and Lichthardt 2004). Considerably more $\mathrm{R}$ plants were detected after the inclusion of an early monitoring period beginning in 2004 (Hill et al. 2014). Two years of monitoring in late May in the Montana demography study reported that $10 \%$ of plants in 1995 and $43 \%$ of plants in 2008 were small plants with 2 or 4 leaves that withered and disappeared quickly; these plants were considered dormant plants in this study (Lesica 1997, 2008).

Studies of other species have demonstrated the presence of vegetative stage classes, larger reproductive stage classes regressing to smaller vegetative stage classes, and survival strategies involving nonreproductive stage classes (Hutchings 1987, Oostermeijer et al. 1996, Wentworth 2000, Kaye 2002, Bruna and Oli 2005).

Prolonged Dormancy.-Previous studies indicate that prolonged dormancy is an important demographic parameter for Spalding's catchfly. The mean annual dormancy rate in the Montana study was high-up to $50 \%-$ and variable, with annual rates ranging from 
$11 \%$ to $74 \%$. Seventy-six percent of dormancies lasted 1 year and $16 \%$ lasted 2 years; the longest dormancy duration was 6 years. The 3 most important transitions involved dormancy. The dormant stage class had the highest total elasticity of any of the stage classes, and survival during dormancy was most critical to population growth. Dormancy was believed to increase fitness because dormant plants were more likely than vegetative plants to flower the following year (Lesica 1997, Lesica and Crone 2007). The Oregon study reported a mean annual dormancy of $42 \%$ with high annual variability. Seventy-five percent of dormancies lasted 1 year, $20 \%$ lasted 2 years, and the remainder lasted 3 years (Taylor et al. 2012).

Our studies indicate that prolonged dormancy is much less important than previously believed. Mean annual dormancy was $10 \%$ $11 \%$ with minimal annual variation of $3 \%-19 \%$. Most dormant episodes (90\%-93\%) were 1-year dormancies, $7 \%-10 \%$ were 2-year dormancies, and only 1 episode was a 3-year dormancy. Dormant plants were more likely to be vegetative plants before and following dormancy. Transition matrix analysis indicated a minor role for dormancy. The D stage class had the lowest total elasticity out of all the stage classes, indicating minimal importance for population growth and fitness. Our late-monitoring dormancy estimates, obtained after many aboveground plants had disappeared, were more similar to the dormancy values obtained in the Oregon and Montana studies (i.e., higher and more variable dormancy rates, longer dormancy durations, and higher total elasticity for the D stage). Several studies have claimed that variable plant counts at flowering from year to year at a site are due to variable rates of annual dormancy (Lesica 1997, Dingeldein et al. 2010, Taylor et al. 2012). Our results, however, suggest that high variability in detection probability of aboveground plants by flowering time may be the more likely cause and may represent much more of a detectability problem for this species than prolonged dormancy.

SEEDLINGS.-The FWS study was the first to document naturally occurring Spalding's catchfly seedlings in the field (Hill et al. 2014). We would not have observed seedlings nor been able to provide information on their appearance and fate over the growing season if we had not monitored early and conducted ground-level searches. The seedlings often occurred in clusters, did not increase in size over the growing season, and generally disappeared by flowering. The cotyledons of the few that were still present and alive at flowering were attached but senescent. The tendency for seedlings to form clusters not only helped us notice them but also indicated that seedheads likely fall to the ground intact. It was relatively common for several seedlings to survive in close proximity for several years.

Transition Probabilities and Growth RATE.-Our results indicate that adult survival is an important life history component of Spalding's catchfly (i.e., stasis and retrogression transitions comprised over three-fourths of the proportional effect on population growth). Monitoring only at flowering in our studies would have indicated much lower stasis transitions and few retrogression transitions. Other studies indicate that long-lived perennials like Spalding's catchfly, especially those in harsh environments, tend to have life histories in which adult survival-represented by both stasis and retrogression-is most important to population growth (Silvertown et al. 1993, Eriksson 1996, Oostermeijer et al. 1996, Picó and Riba 2002). Retrogression, the ability to shrink in size, can result in a higher speed of recovery from disturbance than dying, which requires recruitment to replenish the population (Salguero-Gómez and Casper 2010), particularly in species like Spalding's catchfly that can experience an extended juvenile period. However, anything that affects normally surviving adults and dramatically reduces population size can be catastrophic if not offset by recruitment (Silvertown et al. 1996). The subpopulations sampled in our studies experienced high adult mortality and declining overall growth rates. The BLM population is especially concerning because of very low levels of recruitment. That a Spalding's catchfly population is not reproducing may not be obvious because of low and episodic recruitment, low detectability of seedlings and first-year recruits, and difficulty in distinguishing them from established adult $R$ plants. This makes the accurate determination of recruitment especially important in this species.

\section{Environmental Factors}

Rodent Activity.-Rodent activity was a major threat to Spalding's catchfly in our 
studies and was associated with mortality and declining population growth rates. Rodents appear to target this species, particularly the larger, stemmed plants with the most aboveground vegetation. During episodes of high rodent activity, retrogression transitions from the larger $\mathrm{S}$ and $\mathrm{M}$ plants to the smaller $\mathrm{R}$ plants increased and the $\mathrm{R}$ stage class had a higher survival probability than the $\mathrm{S}$ and $\mathrm{M}$ classes. These responses were likely survival strategies that served to buffer the environmental stress of herbivory by reverting to stage classes less targeted by herbivores or classes with lower mortality (Shefferson et al. 2012). Several studies have shown increases in prolonged dormancy following herbivory (Morrow and Olfelt 2003, Shefferson et al. 2005, Salguero-Gómez and Casper 2010, Shefferson et al. 2012). Few studies have verified rodents as a major threat to this species, although similar observations of damage (vole trails leading to Spalding's catchfly plants and herbivory of below- and aboveground portions of the plants) have been noted in a demography study in Washington (Luke 2013). Although mostly deer mice were trapped at our monitoring sites, the physical evidence was more consistent with damage caused by voles including hidden runways, burrows and holes up to $10 \mathrm{~cm}$ deep, and consumption of underground plant parts; deer mice do not produce hidden runways and are not good burrowers (Baker 1968, Weber and Hoekstra 2009). Cyclic population fluctuations over 3- to 4year periods are well known for montane voles (Elton 1942, Randall and Johnson 1979).

If we had only monitored at flowering time in our studies, we would not have been able to accurately assess the threat from rodent activity. We would not have realized that total plants were considerably underestimated, that many mortalities indicated by late data were false, and that many mortalities that had actually occurred were missed. These errors would have prevented an accurate assessment of the rodent threat and obscured correlation with the causative agent.

Fire.-Our studies indicated several demographic responses to fire not previously reported for this species and regarding the $\mathrm{R}$ stage class in particular. Fire increased retrogression from the larger reproductive stemmed stage classes to the smaller vegetative $R$ stage class and caused a decrease in total elasticity of the usually dominant S stage class accompanied by an increase in total elasticity of the less dominant R stage class. Early monitoring and ground-level searches provided clarification of the role of the $\mathrm{R}$ plant in population dynamics; these responses would not have been detected if we had only monitored at flowering when most $\mathrm{R}$ plants had disappeared. Hill and Garton (2015) also noted a decrease in population growth rates in burned plots.

A major difference between our studies and the Montana demography study was the effect of fire on recruitment. The Montana study reported that burning enhanced recruitment by reducing substantial litter accumulation from rough fescue (Festuca scabrella) (Lesica 1999). Our studies showed no increases in germination (presence of seedlings) or recruitment (presence of first-year recruits) in the 3 years following the wildfire. Similarly, a 2 -year study examining the influence of fire on Spalding's catchfly and its habitat in canyon grasslands on Craig Mountain in Idaho did not show an increase in recruitment at burned sites (Menke and Muir 2004). In our studies, fire reduced biomass and ground litter and caused mortality of mosses and lichens which were a major ground cover component in several of our plots. The darkened soil surface and reduction of plant litter and biomass after fire can increase soil temperature and evaporation, reducing moisture availability in the upper soil depths (de Jong and MacDonald 1975, Redmann 1978, Defossé and Robberecht 1996); this may limit germination following a fire. Germination and recruitment increased markedly as mosses and lichens began to reestablish 3-4 years postfire. Seedlings and first-year recruit $\mathrm{R}$ plants were often observed in close association with reestablishing mosses, and several $\mathrm{R}$ plants were still alive at late monitoring following one of the hottest and driest growing seasons during the study periods. Moss may provide safe sites for germination and help retain soil moisture for subsequent seedling survival, as has been shown for other species (Picó and Riba 2002, Chesser and Brewer 2011, Rayburn et al. 2012). Dew deposition on moss may also have aided seedling survival. Moss-dominated soil crusts are very efficient at condensing water vapor (Kidron et al. 2002). The cool nighttime temperature of moss enhances dew formation (Zhang et al. 2009), and dew forms earlier and 
persists longer on moss compared to other soil crusts or soil substrates, providing more available moisture for associated organisms (Wang et al. 2014).

The difference between the Montana study and our studies regarding the effect of fire on recruitment is likely related to the status assigned to the $\mathrm{R}$ plant and its associated detectability problems. All rosettes in the Montana study were considered recruits, whereas the large majority of rosettes in our studies were found to be established plants, not recruits. Recruitment is difficult to determine in this species. Although seedlings support distinctive cotyledons, they are not consistently observed due to their extremely small size and flushness with the ground surface. First-year recruit $\mathrm{R}$ plants are larger than seedlings, but are still relatively small, located on the ground surface, and ephemeral, usually disappearing by flowering time. Monitoring early in the season and ground-level searches are necessary to detect R plants. First-year recruits do not possess cotyledons and cannot be distinguished morphologically from established juvenile or adult $\mathrm{R}$ plants. Due to prolonged dormancy, it is necessary to track individual plants for at least 2 years to verify that rosettes seen after a fire are actually recruits and not established juvenile or adult plants; this is especially important because retrogressions from $\mathrm{S}$ and $\mathrm{M}$ plants to adult $\mathrm{R}$ plants increased following a fire.

\section{Monitoring Recommendations}

Our findings differ considerably from those of other demographic studies on this species conducted in other regions of its occurrence; however, this is not evidence that the demography of Spalding's catchfly varies by region. It is not possible to make this determination nor to compare populations from different regions until all demographic monitoring studies are conducted in the same way. Our studies demonstrated time- and stage-dependent detectability issues associated with aboveground plants that have considerable potential to bias demographic results. The following monitoring methods are recommended for Spalding's catchfly to eliminate these detectability issues, obtain unbiased demographic estimates to guide management and conservation, and enable comparison of demographic parameters between regions.
Detection of all Aboveground Plants.A primary goal of both demography and trend monitoring is to determine how many plants are present in monitoring plots. Because Spalding's catchfly has an unobservable dormant stage class, it is imperative that all plants that emerge aboveground be detected. One monitoring period conducted soon after emergence (the first or second week in June) that includes ground-level searches for the small $\mathrm{R}$ plant will eliminate the detectability problems associated with aboveground stage classes and the passage of time, allow detection of almost all aboveground plants, and provide unbiased demographic estimates including dormancy. Early monitoring is critical for determining recruitment because first-year recruits were always $R$ plants, recruits often remained in the $\mathrm{R}$ class for several years, and approximately $80 \%$ of $\mathrm{R}$ plants were not detectable at flowering. Observers experienced in identifying Spalding's catchfly $\mathrm{R}$ plants can perform ground-level searches relatively rapidly. The high annual variability in detection probabilities of each aboveground stage class at flowering time decreases their usefulness as correction factors for monitoring at flowering. Early monitoring also essentially eliminates the risk of wildfire destroying a consecutive year of data needed for demographic estimation.

Stage Classes.-Stage classes should be clearly defined and consistently recognizable in the field (Elzinga et al. 1998). Standardized stage classes that can be assigned at early monitoring when all plants are present and detectable should be used in monitoring this species. The R, S, and M aboveground stage classes used in our studies were consistently recognizable at early monitoring and permitted estimates of growth and retrogression components. Reproductive status was not useful as a stage class designation because it was not evident early and was not consistently recognizable at flowering due to plant disappearance, stem loss, herbivory, and fire. Reproductive output could be determined by sampling a subset at flowering time. Other studies have used features other than reproductive status to delineate stage classes. These features include size (rosette diameter, stem height, etc.), number of leaves, and morphological state (Elzinga et al. 1998, Akcakaya 2000).

Criteria for Demographic ParameTERS.-We based our criteria for determining 
recruitment and mortality on the length of dormancy known when we began our studies (i.e., 3 years) (Lesica 1997). Our studies indicated, however, that over $99 \%$ of all dormancies lasted either 1 or 2 years. We therefore recommend adjusting the criterion for recruitment from 3 to 2 initial zeros and the criterion for mortality from 3 to 2 terminal zeros in encounter histories.

Determination of an Individual Plant.It is not possible to quantify and compare abundance between regions nor to determine whether populations have increased to sustainable levels until a standardized definition of an "individual plant" is used in all monitoring studies. Taylor et al. (2012) determined an individual plant as all nonrosette stems within $20 \mathrm{~cm}$ of each other at the soil surface. However, in our studies individual plants (genets) occurred within $2-3 \mathrm{~cm}$ of each other and individual stems of the same plant occurred $8 \mathrm{~cm}$ apart. Other studies have noted the difficulty of distinguishing individual plants (Gamon et al. 2000) and determined that distance between shoots is not a satisfactory indicator of individual plants (Kaye 2002). It is difficult to determine individual plants in this species because of belowground connections of shoots to the caudex, the presence of both single-stem and multistem plants at the same site, and the tendency for several plants to occur in close proximity from recruitment events. Methods that can aid in determining individual plants include finger-tracing stems below the soil surface, moving one stem to detect movement in an adjacent stem, comparing plant locations over several years, and (as a last resort) carefully removing soil around the caudex to reveal connections and then replacing the soil.

Trend Monitoring.-Demographic monitoring procedures (i.e., following marked plants in permanent plots) could be utilized effectively for trend monitoring of this species. Monitoring for 2 consecutive years would yield fairly accurate counts. Monitoring should be conducted soon after emergence and should include systematic ground-level searches for the small $\mathrm{R}$ stage class. All plants should be marked and their locations recorded in the first year. Any additional plants detected in the second year should be added to get the total plants in the plot. Because only $10 \%$ of plants present would be dormant in any given year and $90 \%$ of those would be in a 1-year dormancy, monitoring for 2 consecutive years would detect all plants in 1-year dormancies and probably at least one of the years of any plants in a 2-year dormancy. Plots could be monitored for 2 consecutive years initially to get a baseline population size and then monitored again for 2 consecutive years every $5-10$ years thereafter to determine trend.

\section{Conclusion}

The decline in detectability of aboveground plants of Spalding's catchfly by flowering time has considerable potential to bias demographic estimates and impact conservation and management for this threatened species. Our studies demonstrate the importance of early monitoring and ground-level searches for $\mathrm{R}$ plants in obtaining unbiased demographic estimations for Spalding's catchfly. Our studies also have implications for other plants with small, inconspicuous, ephemeral, or dormant stage classes and those with long growing seasons in harsh environments where detectability of aboveground plant tissue may decrease over the growing season.

\section{ACKNOWLEDGMENTS}

The Bureau of Land Management (Craig Johnson of Cottonwood Resource Area), the U.S. Fish and Wildlife Service (Gina Glenne and Karen Colson), The Nature Conservancy of Idaho (Idaho Field Office of Sun Valley, ID), and the Palouse-Clearwater Environmental Institute (Moscow, ID) provided funding and other support for this project. A special appreciation is extended to Karen Gray, now retired from the Idaho Department of Fish and Game, who was the project leader and primary data collector for the FWS study from 2002 through 2011. Appreciation is also extended to many people that assisted with these studies, including Juanita Lichthardt, Kristen Pekas, Lynn Kinter (who provided many helpful final edits), Bertie Weddell, Sam Fuchs, Joel Sauder, and Tom Schrempp.

\section{Literature Cited}

AKCAKaYA, H.R. 2000. Population viability analyses with demographically and spatially structured models. Ecological Bulletins 48:23-38.

BaKeR, R.H. 1968. Habitats and distribution. Pages 98-126 in J.A. King, editor, Biology of Peromyscus (Rodentia). Special Pub. No. 2, American Society of Mammalogists. 
Bruna, E.M., And M.K. OLI. 2005. Demographic effects of habitat fragmentation on a tropical herb: life-table response experiments. Ecology 86:1816-1824.

Caswell, H. 2001. Matrix population models: construction, analysis and interpretation. 2nd edition. Sinauer Associates, Sunderland, MA.

Chesser, J.D., AND J.S. BREWER. 2011. Factors influencing seedling recruitment in a critically endangered pitcher plant, Sarracenia rubra ssp. alabamensis. Endangered Species Research 13:245-252.

Clark, T.B. 2010. Silene spaldingii (Spalding's catchfly) population vigor and community characteristics in Asotin County, southeastern Washington. Master's thesis, Washington State University, Pullman, WA.

DaubenmiRe, R.F. 1970. Steppe vegetation of Washington. Technical Bulletin 62, Washington Agricultural Experiment Station, Washington State University, Pullman, WA.

Defossé, G.E., and R. Robberecht. 1996. Effects of competition on the postfire recovery of 2 bunchgrass species. Journal of Range Management 49:137-142.

DE Jong, E., AND K.B. MaCDonaLD. 1975. The soil moisture regime under native grassland. Geoderma 14: 207-221.

de Kroon, H., A. Plaisier, J. VanGroenendael, and H. CASWELL. 1986. Elasticity: the relative contribution of demographic parameters to population growth rate. Ecology 67:1427-1431.

Dingeldein, J., R.V. Taylor, H. Schmalz, and V. Jansen. 2010. Demography, phenology and predation of Spalding's catchfly (Silene spaldingii) on the Zumwalt Prairie Preserve, 2006-2009. The Nature Conservancy of Oregon, Northeast Oregon Field Office, Enterprise, OR.

Elton, C.S. 1942. Voles, mice and lemmings. Clarendon Press, Oxford.

Elzinga, C.L., D.W. Salzer, and J.W. Willoughby. 1998. Measuring and monitoring plant populations. BLM Technical Reference 1730-1, U.S. Department of Interior, Bureau of Land Management, Denver, CO.

ERIKSSON, O. 1996. Regional dynamics of plants: a review of evidence for remnant, source-sink and metapopulations. Oikos 77:248-258.

Gamon, J., P.W. Dunwiddie, T. Thomas, and T. Rush. 2000. Assessing the viability of golden paintbrush (Castilleja levisecta). Pages 52-59 in S.H. Reichard, P.W. Dunwiddie, J.G. Gamon, A.R. Kruckeberg, and D.L. Salstrom, editors, Conservation of Washington's rare plants and ecosystems. Washington Native Plant Society, Seattle, WA.

Gray, K., AND J. Lichthardt. 2004. Spalding’s catchfly (Silene spaldingii) monitoring, Craig Mountain, Idaho: 2nd year results. U.S. Fish and Wildlife Service, Snake River Office, Boise, ID. Idaho Natural Heritage Program, Idaho Department of Fish and Game, Boise, ID.

Gray, K., J. Lichthardt, B. Erhardt, and J. Hill. 2011. Post-fire demographic and habitat monitoring of Spalding's catchfly (Silene spaldingii) in Idaho canyon grasslands, Snake and Salmon Rivers (20042010). U.S. Fish and Wildlife Service, Snake River Office, Boise, ID. Idaho Natural Heritage Program, Idaho Department of Fish and Game, Boise, ID.

Hawryzki, A.R., G.A. Allen, and J.A. Antos. 2011. Prolonged dormancy in the geophyte Allium amplectens on Vancouver Island. Botany 89:737-744.

HiLL, J. 2012. Demographic monitoring of Spalding's silene (Silene spaldingii Wats.) in canyon grasslands, Craig
Mountain, Idaho (2002-2011). Final Report. Bureau of Land Management, Cottonwood Resource Area, Cottonwood, ID. Idaho Natural Heritage Program, Idaho Department of Fish and Game, Boise, ID.

Hill, J., and E.O. Garton. 2015. Two long-term demography studies of the Threatened plant species Spalding's catchfly (Silene spaldingii S.Watson) in canyon grasslands in west-central Idaho (2002-2013). U.S. Fish and Wildlife Service, Snake River Office, Boise, ID. Idaho Natural Heritage Program, Idaho Department of Fish and Game, Boise, ID.

HiLl, J., and K. Gray. 2000. Conservation of Spalding's silene (Silene spaldingii) in the Lower Corral Creek Study Area, Garden Creek Ranch, Craig Mountain, Idaho-1999 Field Season. The Nature Conservancy of Idaho, Sun Valley, ID.

Hill, J., AND K. Gray. 2004. Conservation strategy for Spalding' silene (Silene spaldingii Wats.). U.S. Fish and Wildlife Service, Snake River Office, Boise, ID. Idaho Natural Heritage Program, Idaho Department of Fish and Game, Boise, ID.

Hill, J., K. Gray, J. Lichthardt, and K. Pekas. 2014. Demographic and habitat monitoring of Spalding's catchfly (Silene spaldingii) in Idaho canyon grasslands, Snake and Salmon Rivers (2004-2013). Final Report. U.S. Fish and Wildlife Service, Snake River Office, Boise, ID. Idaho Natural Heritage Program, Idaho Department of Fish and Game, Boise, ID.

Hill, J., AND B. Weddell. 2003. Population dynamics of Spalding's catchfly (Silene spaldingii) in the Lower Corral Creek Study Area, Garden Creek Ranch, Craig Mountain, Idaho. 2002 Field Season. Bureau of Land Management, Cottonwood Resource Area, Cottonwood, ID. Palouse-Clearwater Environmental Institute, Moscow, ID.

Hood, G.M. 2010. PopTools version 3.2.5. [Accessed 24 January 2015]. http://www.poptools.org

Horvitz, C.C., AND D.W. Schemske. 1995. Spatiotemporal variation in demographic transitions of a tropical understory herb: projection matrix analysis. Ecological Monographs 65:155-192.

Hutchings, M.J. 1987. The population biology of the early spider orchid, Ophrys sphegodes Mill. I. A demographic study from 1975 to 1984 . Journal of Ecology 75:711-727.

KaYe, T. 2002. Population monitoring for Horkelia congesta ssp. congesta at the Long Tom Area of Critical Environmental Concern. 2002 Progress Report. Bureau of Land Management, Eugene District, Eugene, OR. Institute for Applied Ecology, Corvallis, OR.

Kéry, M., AND K.B. GregG. 2003. Effects of life-state on detectability in a demographic study of the terrestrial orchid Cleistes bifaria. Journal of Ecology 91:265-273.

Kéry, M., K.B. Gregg, and M. Schaub. 2005. Demographic estimation methods for plants with unobservable life-states. Oikos 108:307-320.

Kidron, G.J., I. Herrnstadt, and E. Barzilay. 2002. The role of dew as a moisture source for sand microbiotic crusts in the Negev Desert Israel. Journal of Arid Environments 52:517-533.

Lebreton, J.D., K.P. Burnham, J. Clobert, and D.R. Anderson. 1992. Modeling survival and testing biological hypotheses using marked animals: a unified approach with case studies. Ecological Monographs 62:67-118.

LefKovitCH, L.P. 1965. The study of population growth in organisms grouped by stages. Biometrics 21:1-18. 
LEsICA, P. 1997. Demography of the endangered plant, Silene spaldingii (Caryophyllaceae) in northwest Montana. Madroño 44:347-358.

LesiCA, P. 1999. Effects of fire on the demography of the endangered, geophytic herb Silene spaldingii. American Journal of Botany 86:996-1002.

LEsICA, P. 2008. Detection error associated with observing Silene spaldingii at four sites in Montana and Washington. U.S Fish and Wildlife Service, Snake River Office, Boise, ID.

Lesica, P., and E. Crone. 2007. Causes and consequences of prolonged dormancy for an iteroparous geophyte, Silene spaldingii. Journal of Ecology 95:1360-1369.

LESLIE, P.H. 1945. On the use of matrices in certain population mathematics. Biometrika 33:183-212.

Luke, T.L. 2013. Silene spaldingii Wats. in the channeled scablands of eastern Washington: Demography, monitoring protocol, community characteristics, and habitat modeling. Master’s thesis, Washington State University, Pullman, WA.

MEnKe, C.A. 2003. Relationships of exotic species and wildfire to the threatened plant Silene spaldingii. Master's thesis, Oregon State University, Corvallis, OR.

Menke, C.A., AND P.S. Muir. 2004. Short-term influence of wildfire on canyon grassland plant communities and Spalding's catchfly, a Threatened plant. Northwest Science 78:192-203.

Miller, M.T., G.A. Allen, And J.A. Antos. 2004. Dormancy and flowering in two mariposa lilies (Calochortus) with contrasting distribution patterns. Canadian Journal of Botany 82:1790-1799.

Morrow, P.A., And J.P. Olfelt. 2003. Phoenix clones: recovery after long-term defoliation-induced dormancy. Ecology Letters 6:119-125.

Nichols, J.D., AND K.H. Pollock. 1995. The use of multistate capture-recapture models to address questions in evolutionary ecology. Journal of Applied Statistics 22:835-846.

Oostermeijer, J.G.B., M.L. Brugman, and E.R. DeBoer. 1996. Temporal and spatial variation in the demography of Gentiana pneumonanthe, a rare perennial herb. Journal of Ecology 84:153-166.

Picó, F.X., AND M. RibA. 2002. Regional-scale demography of Ramonda myconi: remnant population dynamics in a pre-glacial relict species. Plant Ecology 161:1-13.

Randall, J.A., And R.E. Johnson. 1979. Population densities and habitat occupancy by Microtus longicaudus and Microtus montanus. Journal of Mammalogy 60:217-219.

Rayburn, A.P., J.B. Davidson, and H.M. White. 2012. Possible effects of moss on distribution and performance of a Threatened endemic primrose. Western North American Naturalist 72:84-92.

Redmann, R.E. 1978. Plant and soil water potentials following fire in a northern mixed grassland. Journal of Range Management 31:443-445.

Reintal, M., K. Tali, M. Haldna, and T. Kull. 2010. Habitat preferences as related to the prolonged dormancy of perennial herbs and ferns. Plant Ecology 210:111-123.

Salguero-Gómez, R., and B.B. Casper. 2010. Keeping plant shrinkage in the demographic loop. Journal of Ecology 98:312-323.

Shefferson, R.P., T. Kull, and K. Tali. 2005. Adult dormancy induced by stress in long-lived orchids. Ecology 86:3099-3104.
Shefferson, R.P., T. Kull, K. Tali, and K.M. Kellett. 2012. Linking vegetative dormancy to fitness in two long-lived herbaceous perennials. Ecosphere 3:1-19.

Shefferson, R.P., B.K. Sandercock, J. Proper, and S.R. VEISSINGER. 2001. Estimating dormancy and survival of a rare herbaceous perennial using markrecapture models. Ecology 82:145-156.

Silvertown, J., M. Franco, and E. Menges. 1996. Interpretation of elasticity matrices as an aid to the management of plant populations for conservation. Conservation Biology 10:591-597.

Silvertown, J., M. Franco, I. Pisanty, and A. Mendoza. 1993. Comparative plant demography-relative importance of life-cycle components to the finite rate of increase in woody and herbaceous perennials. Journal of Ecology 81:465-476.

Taylor, R.V., J. Dingeldein, and H. Schmalz. 2012. Demography, phenology and factors influencing reproduction of the rare wildflower Spalding's catchfly (Silene spaldingii) on the Zumwalt Prairie. The Nature Conservancy of Oregon, Northeast Oregon Field Office, Enterprise, OR.

TisDale, E.W. 1986. Canyon grasslands and associated shrublands of west-central Idaho and adjacent areas. Bulletin 40, Forest, Wildlife, and Range Experiment Station. University of Idaho, Moscow, ID.

Tremblay, R.L., M. Perez, M. Larcombe, A. Brown, J. Quarmby, D. Bickerton, G. French, and A. Bould. 2009. Dormancy in Caladenia: a Bayesian approach to evaluating latency. Australian Journal of Botany 57:340-350.

[USFWS] United States Fish and Wildlife Service. 2001. Endangered and Threatened wildlife and plants; final rule to list Silene spaldingii (Spalding's catchfly) as Threatened. Federal Register 66:51598-51606.

[USFWS] United States Fish and Wildlife Service. 2007. Recovery plan for Silene spaldingii (Spalding's catchfly). U.S. Fish and Wildlife Service, Portland, OR.

Wang, X., Y. Pan, R. Hu, Y. Zhang, and H. Zhang. 2014. Condensation of water vapour on moss-dominated biological soil crust, NW China. Journal of Earth System Science 123:297-305.

Weber, J.N., AND H.E. Hoekstra. 2009. The evolution of burrowing behaviour in deer mice (genus Peromyscus). Animal Behavior 77:603-609.

Wentworth, J.B. 2000. The demography and population dynamics of Castilleja levisecta, a federally threatened perennial of Puget Sound grasslands. Pages 4951 in S.H. Reichard, P.W. Dunwiddie, J.G. Gamon, A.R. Kruckeberg, and D.L. Salstrom, editors, Conservation of Washington's rare plants and ecosystems, Washington Native Plant Society, Seattle, WA.

White, G.C., AND K.P. BuRnhaM. 1999. Program MARK: survival estimates from populations of marked animals. Bird Study 46:S120-S139.

ZAR, J.H. 1984. Biostatistical analysis. 2nd edition. Prentice Hall, Inc., Upper Saddle River, NJ.

Zhang, J., Y. Zhang, A. Downing, C. Jun-hui, Z. XiaoBING, AND Z. BING-CHANG. 2009. The influence of biological soil crusts on dew deposition in Gurbantunggut Desert, northwestern China. Journal of Hydrology 379:220-228.

Received 14 June 2016

Accepted 9 January 2017

Published online 27 March 2017 